\title{
To THE EDITOR
}

Writing in the Fall/Winter 1987 issue of Slavic Review, David Engel devotes a full twelve pages to commenting upon a brief book review published in 1986 in Slavic Review. This review generally praised a book by Richard Lukas, The Forgotten Holocaust: The Poles under German Rule, 1939-1944 (Lexington: University Press of Kentucky, 1986).

After having read Engel's attack upon Lukas's scholarship in his so-called ongoing discussion, Lukas's response, and the entire book itself, I find it really difficult to understand either Engel's complaint or why you decided to publish his very extended comments. I hope it is not to discourage scholars from studying the subject of Lukas's research.

In the introduction to his book, Lukas states clearly his purpose. In his judgment, historians of the Holocaust have focused exclusively upon the tragic fate of the Jewish victims of Nazi genocide and have "little or nothing to say about the nine million Gentiles, including three million Poles who also perished in the greatest tragedy the world has ever known." He goes on to write that it is ironic "that Poland, the nation that suffered the cruelest occupation policies of the Germans during World War II, has had so little written about its wartime experience. . . . This book is an attempt to fill that void" (p. xi).

Lukas's book is thus about the ruthless character of Nazi rule in Poland. He focuses upon Nazi policies in Poland and upon the considerable and heroic efforts by Polish gentiles to fight back, often effectively, against their tormenters. This story is a part of the larger history of World War II on the eastern front (as well as the postwar fate of Poland) that even now has not received the scholarly attention that it deserved.

Engel, however, has another book in mind, one which he believes Lukas ought to have written instead. It is the story of Polish gentile attitudes and conduct toward the Jewish citizens of Poland before and during the war. Indeed, in his lengthy essay one does not find even an acknowledgement from Engel about the ferocity of Nazi terror against the Polish gentiles, which is one of Lukas's central themes. Nor, unfortunately, is there any mention of gentile efforts to save Jewish lives. As disappointing is Engel's silence about the historic reality of nearly eight hundred years of Jewish community life in Poland, most of it experienced in conditions of cultural vitality and social toleration unknown anywhere else in Europe. Indeed, how is it that Poland, of all the European lands, became the home of perhaps 70 percent to 75 percent of the world's Jews by the eighteenth century? Engel is uninterested in this question, as are practically all scholars of the fate of the European Jews. Yet this subject fairly cries out for study - why was toleration practiced toward so many and for so long?

I believe there is a great need for western scholarship on the tragedy of the wartime destruction of the Jews to analyze carefully the concept of anti-Semitism in terms of its historical context and to make the basic distinction between the phenomenon of anti-Semitism and the conduct of the Nazis, which included systematic policies of genocide. While anti-Semitism was certainly at the heart of Nazi thinking about the Jews, it does not explain their behavior in nearly wiping out the Gypsies, another "forgotten people" victimized by Nazi genocide. Nor does it explain Nazi conduct toward the Poles and other Slavic peoples, who suffered so mercilessly at their hands. Until scholars make the proper distinctions in conceptualization and basic terminology about the aims and justifications of Nazi conduct, we will not progress in performing genuine scholarly pursuits leading to a better grasp of the truth of the matter.

I, for one, commend Lukas for his serious, courageous research effort and trust it will gain a sizeable readership. I lament Engel's statement and especially his closing comment about Lukas's work, that until he looks at things as Engel has, Lukas had better simply remain silent (p. 580). 